\title{
Character education in English package books for Islamic Junior High School students
}

\author{
Wahyuningsih Usadiati ${ }^{1}$, Maida Norahmi ${ }^{2}$ \\ ${ }^{1,2}$ English Education Study Program, Languages and Arts Department, Teacher Training and \\ Education Faculty, Universitas Palangka Raya, Indonesia \\ ${ }^{1}$ wahyu.usadiati@edu.upr.ac.id \\ ${ }^{2}$ maida.norahmi12@edu.upr.ac.id (corresponding author)
}

Received: May 12, 2019; Accepted: September 27, 2019; Published: September 29, 2019

\begin{abstract}
The research is an inventory aimed at identifying and categorizing the character values in the English package books for students of Islamic Junior High School or Madrasah Tsanawiyah by considering their relevance to Islamic character values in the Quran and Hadits. The method used was content analysis following Bogdan and Biklen model by analyzing, grouping, sorting, and synthesizing the values taken from the package books to draw the patterns. The patterns were discussed to conclude the final findings to be disseminated as the list of inventory. The main data source was the English package books published by the government and the supporting data were the Core Competencies taken from Curriculum 2013 for Junior High School (SMP) and Madrasah Tsanawiyah (MTs) or Islamic Junior High School students. There are 10 values inserted in the package books that are relevant to the Islamic religious characters. The result showed various English expressions relevant to Islamic character values which have a long-term and sustainable effect as a reference for character building by English teachers in developing English supplementary materials for Islamic Junior High School students.

Keywords: character education; package books; religious values; Islamic Junior High School; Madrasah Tsanawiyah

How to cite this paper (in APA style): Usadiati, W., \& Norahmi, M. (2019). Character education in English package books for Islamic Junior High School students. Journal on English as a Foreign Language, 9(2), 181-198. doi:http://dx.doi.org/10.23971/jefl.v9i2.1298
\end{abstract}


DOI: http://dx.doi.org/10.23971/jefl.v9i2.1298

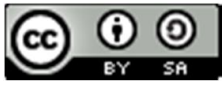

Character education is an old term to address the efforts to teach and cultivate good characters in students' behaviors. The good characters are expected to wrap individuals' knowledge and skills and to strengthen their personality to be ready in undergoing their future. In Indonesia, the objective of education at any level is to produce graduates with not only academic achievement but also a good character. The objective means that to be successful in the age of automation and smart system today, character education will still be needed to accompany knowledge (Suyitno, 2012). Although the nature of education will need to change and the role of schools, will, in some ways, be very different in the future (Gill, 2017), character education has to still be integrated in the teaching and learning process where the students have the freedom to express themselves and to build their academic, social, and emotional aspect (Suyanto, 2012). Character education is integrated into teaching to make the students develop and motivate their moral senses to grow. The values as the result of this moral growth are related to social behaviors, moral reasoning, emotional competencies, moral identity, self-system, and all the values that support their sense of humanity (Berkowitz \& Bier, 2007).

Moral growth is one of the crucial factors to be owned by the students since it helps directly in what way they will implement the knowledge and skills they have. As stated by the Indonesian Minister for Research, Technology, and Higher Education (2018), New Literation facing the industrial revolution does not only mean to have data literation and technology literation, but also human literation. Character education, as one aspect in human literacy, is generally related to religious values as the reference in attitude (Sutarman, Edi Hermawan, \& Ahmad, 2017). Research results conducted by Marini (2017) concluded that $65.1 \%$ of 63 elementary schools in Jakarta has already integrated character building in their preliminary, core, and closing activities in the teaching and learning process. Meanwhile, research results conducted by Hadi (2015) have also shown the way that teachers in Banjarmasin integrated character values while teaching subject matter content was for the sake of building quality and credibility of human resources.

Human resources and good characters are closely related in terms that both aspects can support and complete each other. Human resources are not only related to knowledge and skills but also morality to maintain social and emotional competencies. This is one of the reasons why character education has 
been included in Naskah Rencana Aksi Nasional Pendidikan Karakter since 2010 (Indonesian Ministry of National Education, 2010). For this purpose, character education has been integrated into the activities of teaching and learning process in Junior and Senior High Schools in Indonesia, as stated in Kurikulum 2013. To implement the plans, the government has launched the Presidential Decree number 87 the year 2017 which also states the need for strengthening character education starting from elementary up to university students, for both formal and non-formal education based on foundational philosophical theory of Indonesia (Moniung \& Prayogo, 2018). This is all done to be able to overcome social problems and character building in the society through education. The most essential need for the implementation of character education in Indonesia is to cultivate the goodwill in the hearts of the students to be better human displaying the good character in their social life through character education (Sutjipto, 2011).

Concerning character education, the government put a serious concern on the issue of character building that a new curriculum was launched to replace the KTSP curriculum. The new curriculum, Curriculum 2013, was created to fulfill the expectation of more inserting good values and characters into the teaching and learning activities. To implement teaching and learning activities based on the competence to be reached by the students stated in Curriculum 2013, the government has prepared English package books for Junior High School students. The package books contain general English teaching materials consisting of the four language skills (listening, speaking, reading, and writing) and components of English (pronunciation, vocabulary, and grammar). The available English package books nowadays consist of 'When English Rings a Bell' for grades VII dan VIII SMP MTs written by Wachidah et al. revised and published in 2017, and 'Think Globally Act Locally' for grade IX SMP MTs prepared by Wachidah, Diyantari, and Khatimah (2015). The package books are published by the Ministry of Education and Culture as the standard books for English teaching and learning process. In regard that Islamic schools also implement Islamic character values in their curriculum, confirmation has to be considered to also include Islamic character values in the supplementary materials. This is in line with the agenda to cultivate character education since the very beginning to be integrated into the teaching and learning process (Budiwibowo, 2016). With this in mind, then, teachers need to develop supplementary materials containing religious values.

The supplementary materials will be a crucial need as media in the teaching and learning process, in which religious values can be displayed and 
implemented. As stated by Sutjipto (2011), the sources of character education, especially for Islamic schools, consist of Islamic values, Pancasila (the Indonesian state philosophy), such as honesty, curiosity, politeness, discipline, hard work, creativity, self-help, care, tolerance, internal motivation, healthy lifestyle, responsibility, confidence, and friendly-life environment. Further, Moniung and Prayogo (2018) stated that by considering the existence of government documents supporting the character education, all of the educational units including schools, society, as well as family might play a role in strengthening characters, including religious values, honesty, tolerance, discipline, hard work, creativity, self-help, democracy, curiosity, the spirit of nationality, the pride of the country, appreciation of achievement, communication, peace lover, reading motivation, friendly-life environment, social care, and responsibility. All of these good characters might be well implemented in educational units, i.e. schools, in that the students should obtain character education in their learning process. Similar to the statement, Gunawan (2012) also stated that the objective of character education in Indonesia is to institutionalize character values to establish tough nationality with competitiveness, good morality, tolerance, patriotism, dynamic, oriented towards science and technology, all of which are in favor of faith and piety to God based on Pancasila.

Institutionalization of character values in character education cannot be separated from the religious education from which the good values and characters are extracted. As stated by Sukardi (2016), the final goal of religious education is to have attitude and behavior with noble character, such as being reflective, confident, rational, logical, critical, analytical, creative and innovative, independent, healthy living, responsible, love science, patient, cautious, self-sacrificing, courageous, trustworthy, honest, keeping promises, fair, humble, shy err, forgiving, soft-hearted, loyal, hard-working, diligent, tenacious/persistent, meticulous, initiative, positive thinking, discipline, anticipatory, initiative, visionary, humble, passionate, dynamic, efficient/ inefficient, appreciate the time, dedication, self-control, productive, friendly, love of beauty (aesthetics), sportsmanship, resilient, open, orderly. In the Islamic perspective, Musrifah (2016) stated that character education is an effort to teach good character, morals, and ethics in daily life to worship and socialize in society. That is why rukun Islam which has to be obeyed by Muslims can be used as media to develop supplementary reading texts with character education integrated into them. Based on the sources of character values applied in the education system in Indonesia, religion is placed as the main source of character education. This means that religious values are placed as the 
main pillars in the education system that they cannot be separated from character building in developing human resources through education.

Regarding the current issue of character building containing religious values which should be inserted in the learning materials, how to insert the values intended in more explicit description, and what values are similar to the religious aspects, this research provides an inventory list of the characters as a guideline for the teachers to develop their learning materials. Besides, this research provides access to teachers' creativity and local-based content to be more promoted in English teaching and learning process. By doing content analysis on the English package books published by the government, this research was intended to identify and categorize the characters which were inserted in the supplementary materials of the books and were in line with the Islamic religious values. The result of the research was expected to create a list of the characters as the guidelines to develop English supplementary materials for the teachers to teach English in Islamic High Schools.

\section{METHOD}

The research used a qualitative research method to analyze the content of government-published book When English Rings a Bell and Think Globally Act Locally. The research followed the procedure of content analysis model by Bogdan and Biklen (1982) which was divided into seven stages, i.e. data analysis, data organization, data selection, data synthesis, pattern drawing, reporting, and dissemination of the finding, to help the researchers create the list of inventory research. The inventory research was conducted to identify and to categorize character values in the English package books for Islamic High School students in Palangka Raya by considering their relevance to the character values as stated in the Quran and Hadits. The identification and categorization were done to know whether the statements expressed in the English package books have been relevant to the character values based on the Islamic religion. The research was also conducted to give the basics for the enrichment of supplementary English Package Books for Islamic Junior High School students by integrating abstract character values based on Islamic perspectives into concrete English teaching materials.

\section{Data Collection}

To conduct research following Bogdan and Biklen model, the data must be adequately available. To prepare the data to be analyzed, the researchers collected the data from primary and secondary sources. The primary sources

Journal on English as a Foreign Language, 9(2), 181-198

Copyright @ 2019 by JEFL, p-ISSN 2088-1657; e-ISSN 2502-6615 
were the package books published by the government for Junior High School level, named When English Rings a Bell for the seventh- graders, When English Rings a Bell for the eighth-graders, and Think Globally Act Locally for the ninthgraders. Each revised version of the books for those three grades was downloaded from the official website. After reading and checking the books, then the discussion was to decide which versions would be used as the main data. The agreement was to use the latest versions of the books, in e-book forms, since they were revised to fix the weaknesses of the previous versions and has been widely used by the teachers. The secondary data, the Core Competence document for the English subject, was taken from the documents of Curriculum 2013 which was also downloaded from the official website. The Core Competence was used as a reference for the values intended for the English subject. Both kinds of data were printed and copied as many as they were needed before conducting the data analysis.

\section{Data Analysis}

As the first step of the research model, the data analysis was done to identify and categorize the intended values throughout the contents of the books. The main data source consisted of the English package books for Grade VII, VIII and IX for Islamic High School students. To strengthen the data analysis results, the Core Competence stated in Curriculum 2013 was treated as the reference to guide the researchers in finding the values inserted in the books. The Digital Quran and Hadiths were also referred and consulted to see the relevance of the values in the books with Islamic values for character building. After the analysis was finished, every value that appeared in the books was listed. The list was the first draft of the inventory result, but it still needed to compare to the other sources.

\section{Data Organization}

Organizing the data was done by grouping the values based on their nature such as in term of personal characters, interpersonal characters, living in social life, and environmental-based activities. Those groups were obtained by seeing the relations of the benefits or effects of having such values or considering the reasons why those values were suggested to be owned. The data organization was put in the column to separate the values based on their categories. This was needed to be done since the specification of the values would help the researchers to sort the relevant values. 


\section{Data Selection}

To support the result of the analysis and the categorization, the values listed were compared to the Core Competence stated in Curriculum 2013 to ensure that the analysis result was still in the line with the government documents. Regarding the Islamic religious values, it was extremely important to compare the analysis result to the Quran and Hadiths to find out the Surah and the verses in which the values appeared. After the data were compared and irrelevant data were eliminated, a list of the values was prepared to be sent to two validators as the expert to give feedbacks and revision on the list. The first validator was an expert in Islamic religious values and an English teacher, and the second was a Ph.D. candidate who is still conducting his research on the Islamic values in English language teaching. Based on their feedback and suggestions, the list was reviewed and the final selection was conducted.

\section{Data Synthesis}

After the final selection was conducted and the irrelevant data were eliminated, the further draft of the list was compared to the references related to character education. The previous research results and the theories of character education were consulted to synthesize the values obtained during the three stages. The theories were involved to strengthen whether the data could be included in the characters inserted in character education. Results of the literature review led the researchers to get feedback and additional data for the final draft.

\section{Pattern Drawing}

In drawing the patterns, the researchers reviewed and discussed the final draft to see whether some values were closely related to each other. This was the final stage in the revision of the list since in this stage certain values could be merged into the others based on which values give more impact. The patterns would also show whether the first categories remained as it was or it needed some revisions. The relevance of the values was viewed from how many times the values were inserted in the expressions taken from the books. Sometimes, certain different values might appear only once and they could be possibly merged to another value that covered the same meaning. 


\section{Finding Report}

By reporting the findings, the main trends of the values could also be seen. The trends were intended effort to insert certain major values in the learning materials for their urgency. The efforts of building good characters should be gradually done since it needed more time to cultivate certain abstract ideas. The trends would be reported based on the frequency of appearance and it was assumed to be consistent throughout the three books. Then, the reasons why such trends existed should be consulted to other supporting documents, such as the Core Competence, curriculum objectives, and the latest happening issues. The finding report would be the final draft of the list of the values.

\section{Finding Dissemination}

This was the last stage of this inventory research using the content analysis. Since the findings were informed in the report and the list of the values was already arranged as the final result, it was the time to distribute the finding report (the list of the values) to the future users, English teachers in Islamic High Schools. Some of the representative teachers for state and private Islamic High Schools in Palangka Raya were invited to come to the dissemination program. They were asked to read the list and to give their comments on the listed values. To strengthen the result of the research, an informal interview was conducted to have deeper information from the teachers. Results of the interview were analyzed to get feedback and additional data for the final revised list of the values. The final result was distributed to the teachers so that it could be used during the English material development and inserted into the teacher-made materials both to supplement the use of the English package books and to support the character education integrated into English teaching and learning process.

\section{FINDINGS}

The character values analyzed were taken from When English Rings a Bell for the seventh and the eighth graders and Think Globally Act Locally for the ninth graders. The English package books were treated as the main source of data. To provide more information about the books, it is shown in Table 1. Table 1 shows the books that were used for Grade VII, VIII, and IX of Islamic High School students in Palangka Raya. The information related to the publication year and revised edition is also provided to set the specification of the books since there are some differences in a different revised version. The researchers decided to use the latest publication and versions. 
Table 1. English package books used for Islamic junior high school students in Palangka Raya

\begin{tabular}{clcl}
\hline No. & \multicolumn{1}{c}{ Book title } & Grade & \multicolumn{1}{c}{ Publisher } \\
\hline 1 & When English Rings a Bell & VII & $\begin{array}{l}\text { Kemendikbud, 4th edition } \\
\text { (revised), 2017 }\end{array}$ \\
2 & When English Rings a Bell & VIII & $\begin{array}{l}\text { Kemendikbud, 2nd edition, } \\
\text { (revised), 2017 }\end{array}$ \\
3 & $\begin{array}{l}\text { Think Globally Act } \\
\text { Locally }\end{array}$ & IX & Kemendikbud, 1st edition, 2015 \\
\hline
\end{tabular}

The Core Competence of English for Islamic High School students as the secondary data were taken from Kerangka Dasar dan Struktur Kurikulum 2013 (Depdiknas, 2013). The Core Competence is stated here since this is the main reference of the character values analyzed and concerned.

Table 2. Core Competence for Grades VII, VIII, and IX students of Islamic high schools in Palangka Raya

\begin{tabular}{|c|c|c|}
\hline Grade & Core Competence 1 (KI 1) & Core Competence 2 (KI 2) \\
\hline VII & $\begin{array}{l}\text { Appreciate and live up to } \\
\text { religion the students } \\
\text { embrace }\end{array}$ & $\begin{array}{l}\text { Appreciate and live up to the attitudes of } \\
\text { being honest, discipline, responsible, care } \\
\text { (tolerance, mutual help), polite, confident, } \\
\text { curious in effectively interacting with the } \\
\text { social and natural environment in the } \\
\text { surroundings }\end{array}$ \\
\hline VIII & $\begin{array}{l}\text { Appreciate and live up to } \\
\text { religion the students } \\
\text { embrace }\end{array}$ & $\begin{array}{l}\text { Appreciate and live up to the attitudes of } \\
\text { being honest, discipline, responsible, care } \\
\text { (tolerance, mutual help), polite, confident, } \\
\text { curious in effectively interacting with the } \\
\text { social and natural environment in the } \\
\text { surroundings }\end{array}$ \\
\hline IX & $\begin{array}{l}\text { Appreciate and live up to } \\
\text { religion the students } \\
\text { embrace }\end{array}$ & $\begin{array}{l}\text { Appreciate and live up to the attitudes of } \\
\text { being honest, discipline, responsible, care } \\
\text { (tolerance, mutual help), polite, confident, } \\
\text { curious in effectively interacting with the } \\
\text { social and natural environment in the } \\
\text { surroundings }\end{array}$ \\
\hline
\end{tabular}

(Source: The Indonesian Ministry of Education and Culture, 2013)

Table 2 presents the information related to the grade, the content of Core Competence 1, and the descriptions of Core Competence 1 into Core Competence 2. In Core Competence 1, the learning objectives seem to be more general, since it is the final goal that should be reached. Meanwhile, in Core 
Competence 2, the general goal is broken down into more detailed attitudes or values that should be owned to reach the general goal in Core Competence 1.

The analysis and synthesis were conducted by tabulating the character values found in the English Package Books that have been consulted to the Digital Quran and Hadith, as stated in Table 3. The character values found have been validated by the two validators to get their feedback. The results have been distributed to teachers of Islamic Junior High Schools in Palangka Raya to be integrated into their teaching and learning activities.

In Table 3, the information of character values obtained after the content analysis is included. There are ten character values obtained from the three books analyzed. The ten-character values are relatively similar across the three grades. It can be concluded that the values are the main characters to be owned by the students after learning the materials. The number of statements means the frequency of appearance of certain values. To make it more specified and obvious, the examples of statements and expressions taken from the books are included in the last column. It also provides the information in what chapter and page the statements or the expressions can be found.

In When English Rings a Bell for the seventh grade, the value that has the highest frequency of appearance is being, tolerant which appears in 42 statements and expressions. Differently, 20 statements are containing the value of being disciplined. This is the highest frequency of appearance in When English Rings a Bell for the eighth grade. The last, in Think Globally Act Locally for the ninth grade, the highest frequency of appearance among the values is being tolerant in 55 statements and expressions. Although the value of being tolerant is the highest, from the table, it can also be seen that being polite and discipline appear in more than 25 statements and expressions.

In brief, there are some dominant values found in each book. It signals that certain values have more concerns than others. The consideration possibly relates to the current issues in social life regarding the multicultural communities (being tolerant and being polite) and the efforts to shape the students' personality (being discipline). In fact, the three dominant values are also the values that frequently appear in Islamic religious values. This kind of similarities becomes the floor for the researcher to create the inventory list as a guide those who want to develop supplementary materials based on the character-building approach and Islamic perspectives. 
Table 3. Character values in the English package books for Islamic junior high school students in Palangka Raya

\begin{tabular}{|c|c|c|c|}
\hline No. & $\begin{array}{l}\text { Character } \\
\text { value }\end{array}$ & $\begin{array}{l}\text { Number of } \\
\text { statements }\end{array}$ & Example of the statement (expression) \\
\hline \multicolumn{4}{|c|}{$\begin{array}{l}\text { English package book title: When English Rings a Bell, Grade VII } \\
\text { (Total chapters =8) }\end{array}$} \\
\hline 1 & Honest & 9 & $\begin{array}{l}\text { Wow! Your classroom is clean, nothing is } \\
\text { dirty and messy. (Chapter V page 100) }\end{array}$ \\
\hline 2 & Discipline & 9 & $\begin{array}{l}\text { On Wednesday, I learn Engish at half-past } \\
\text { nine. (Chapter } 3 \text { page 57) }\end{array}$ \\
\hline 3 & Responsible & 8 & $\begin{array}{l}\text { Edo prepares his stuff for school tomorrow. } \\
\text { (Chapter } 3 \text { page } 42 \text { ) }\end{array}$ \\
\hline 4 & Care (tolerant) & 42 & $\begin{array}{l}\text { I help my mom wash the dishes before I go } \\
\text { to school. (Chapter } 6 \text { page 136) }\end{array}$ \\
\hline 5 & Polite & 25 & $\begin{array}{l}\text { Wow. Thanks. That's very mindful of you. } \\
\text { (Chapter } 7 \text { page 153). }\end{array}$ \\
\hline 6 & Confident & 2 & $\begin{array}{l}\text { Ok. I'm sure will find it. } \\
\text { (Chapter } 7 \text { page } 151 \text { ) }\end{array}$ \\
\hline 7 & Curious & 15 & $\begin{array}{l}\text { Do you know the building on the right, } \\
\text { across the bank and the post office? (Chapter } \\
4 \text { page } 67 \text { ) }\end{array}$ \\
\hline 8 & $\begin{array}{l}\text { Motivated } \\
\text { (internal) }\end{array}$ & 5 & $\begin{array}{l}\text { Beni, let's go to school early tomorrow, so } \\
\text { we can study together before the English } \\
\text { test. (Chapter } 6 \text { page 136) }\end{array}$ \\
\hline 9 & $\begin{array}{l}\text { Healthy } \\
\text { lifestyle }\end{array}$ & 8 & $\begin{array}{l}\text { We can play badminton and so many } \\
\text { activities. } \\
\text { (Chapter } 5 \text { page } 103 \text { ) }\end{array}$ \\
\hline 10 & $\begin{array}{l}\text { Friendly live } \\
\text { environment }\end{array}$ & 10 & $\begin{array}{l}\text { We can keep this park clean. } \\
\text { (Chapter } 5 \text { page } 100)\end{array}$ \\
\hline
\end{tabular}

English package book title: When English Rings a Bell, Grade VIII (Total chapters $=13$ )

\begin{tabular}{llcl}
\hline 1 & Honest & 4 & $\begin{array}{l}\text { I think Riri is the most interesting orphan I } \\
\text { have ever known. (Chapter 8 page 15) } \\
\text { We must wear a uniform every day. }\end{array}$ \\
3 & Discipline & 12 & $\begin{array}{l}\text { (Chapter 3 page 40). } \\
\text { I should be more careful now. } \\
\text { (Chapter 3 page 37) }\end{array}$ \\
4 Care (tolerant) & $13 \quad \begin{array}{l}\text { If you need any help with your laundry, } \\
\text { please let know. I will come to your house to } \\
\text { help you. (Chapter 2 page 29) } \\
\text { Excuse me, ma'am. } \\
\text { (Chapter 1 page 6) }\end{array}$ \\
\hline
\end{tabular}

Journal on English as a Foreign Language, 9(2), 181-198

Copyright @ 2019 by JEFL, p-ISSN 2088-1657; e-ISSN 2502-6615 


\begin{tabular}{|c|c|c|c|}
\hline 6 & Confident & 6 & $\begin{array}{l}\text { I think Bono will win the race! } \\
\text { (Chapter } 9 \text { page } 120 \text { ) }\end{array}$ \\
\hline 7 & Curious & 11 & $\begin{array}{l}\text { You said your little sister did something } \\
\text { funny this morning. What is that? (Chapter } \\
11 \text { page } 187 \text { ) }\end{array}$ \\
\hline 8 & $\begin{array}{l}\text { Motivated } \\
\text { (internal) }\end{array}$ & 2 & $\begin{array}{l}\text { If you do it together, I am sure you can } \\
\text { understand it easily. (Chapter } 2 \text { page } 23 \text { ) }\end{array}$ \\
\hline 9 & $\begin{array}{l}\text { Healthy } \\
\text { lifestyle }\end{array}$ & 2 & $\begin{array}{l}\text { Thomas: "Smoking is bad. But smoking in } \\
\text { public is worse." (Chapter } 9 \text { page 132) }\end{array}$ \\
\hline 10 & $\begin{array}{l}\text { Friendly live } \\
\text { environment }\end{array}$ & 6 & $\begin{array}{l}\text { We water the plants too. } \\
\text { (Chapter } 7 \text { page } 94 \text { ) }\end{array}$ \\
\hline \multicolumn{4}{|c|}{ Total statement: 86} \\
\hline \multicolumn{4}{|c|}{$\begin{array}{l}\text { English package book title: Think Globally Act Locally, Grade IX } \\
\text { (Total chapters }=14)\end{array}$} \\
\hline 1 & Honest & 2 & $\begin{array}{l}\text { I think you can try guava leaves. In fact, I } \\
\text { have brought some for you. (Chapter } 3 \text { page } \\
\text { 37)/ }\end{array}$ \\
\hline 2 & Discipline & 27 & $\begin{array}{l}\text { I have practiced every day for the last two } \\
\text { months with my dad. (Chapter } 1 \text { page } 4 \text { ) }\end{array}$ \\
\hline 3 & Responsible & 17 & $\begin{array}{l}\text { She does the chores and takes care of her } \\
\text { younger sisters and brothers all the time. } \\
\text { (Chapter } 9 \text { page } 178 \text { ) }\end{array}$ \\
\hline 4 & $\begin{array}{l}\text { Care } \\
\text { (tolerance) }\end{array}$ & 55 & $\begin{array}{l}\text { If you have any problem, come to me. } \\
\text { (Chapter } 1 \text { page } 5 \text { ) }\end{array}$ \\
\hline 5 & Polite & 34 & $\begin{array}{l}\text { Thanks. I hope so, too. } \\
\text { (Chapter } 1 \text { page } 14 \text { ) }\end{array}$ \\
\hline 6 & Confident & 12 & $\begin{array}{l}\text { The song sends a message that we have to be } \\
\text { optimistic in life. (Chapter } 7 \text { page 138) }\end{array}$ \\
\hline 7 & Curious & 11 & $\begin{array}{l}\text { That cloth is beautiful. Is it made in } \\
\text { Indonesia? } \\
\text { (Chapter } 11 \text { page } 208 \text { ) }\end{array}$ \\
\hline 8 & $\begin{array}{l}\text { Motivated } \\
\text { (internal) }\end{array}$ & 14 & $\begin{array}{l}\text { I hope so too, ma'am. Yes, I'll do my best. } \\
\text { (Chapter } 1 \text { page } 2 \text { ) }\end{array}$ \\
\hline 9 & $\begin{array}{l}\text { Healthy } \\
\text { lifestyle }\end{array}$ & 11 & $\begin{array}{l}\text { Listen, everybody, never forget to wash } \\
\text { your fruits and vegetables before you eat } \\
\text { them. (Chapter } 3 \text { page } 37 \text { ) }\end{array}$ \\
\hline 10 & $\begin{array}{l}\text { Friendly live } \\
\text { environment }\end{array}$ & 5 & $\begin{array}{l}\text { "Pick up the trash and put it in the bin". } \\
\text { (Chapter } 3 \text { page } 40 \text { ) } \\
\text { statements: } 163\end{array}$ \\
\hline
\end{tabular}

Journal on English as a Foreign Language, 9(2), 181-198

Copyright (C) 2019 by JEFL, p-ISSN 2088-1657; e-ISSN 2502-6615 


\section{DISCUSSION}

The results of analysis and synthesis of the three English package books for grades VII, VIII, and IX for Islamic High School students show that the statements in the package books have been relevant to Islamic character values in form of expressions. In English Package Book for Grade VII (Wachidah, Gunawan, Diyantari, \& Khatimah, 2017a), there are 133 statements expressing honesty, discipline, responsibility, care (tolerance), politeness, confidence, curiosity, motivation (internal), healthy lifestyle, and friendly live environment. Meanwhile, there are 86 and 163 expressions of similar character values respectively in English Package Book for Grades VIII (Wachidah, Gunawan, Diyantari, \& Khatimah, 2017b) and IX (Wachidah, et al., 2015). The character values are elaborated from the Core Competencies KI 1 and KI 2 stated in Curriculum 2013 for the students to obtain character education in their learning process. The values above are elaborated as follows.

Firstly, honesty as a good character in Islam can be found in the package books above. For example, the expression "Wow! Your classroom is clean, nothing is dirty and messy" in the package book 'When English Rings a Bell' Chapter V page 100 shows a statement of being honest to see the classroom. Meanwhile, the expression "We must wear a uniform every day" in Chapter 3 page 40 of the package book for Grade VIII show the act of being disciplined. Being responsible can also be traced from the expressions in the English Package Books. In Chapter 9 page 178 of the package book 'Think Globally Act Locally', the expression 'She does the chores and takes care of her younger sisters and brothers all the time' for example, might also invite students to do the same responsibility at home.

Secondly, conversation in Chapter 2 page 29 in the package book 'When English Rings a Bell' for Grade VII ("If you need any help with your laundry, please let know. I will come to your house to help you."), for example, can be articulated as one of the character values in Islam as being care (tolerance). This conversation leads the students to reflect it in their daily life at school or home.

Thirdly, being polite is also a good character value in Islam. This is shown in the package book 'When English Rings a Bell' for Grade VIII in the expression "Excuse me, ma'am" on Chapter 1 page 6. Students always asking permission before doing anything might show that they know how to behave politely, and this can be exemplified in the expressions of the package books. Regarding this, the materials need to teach that the students have to treat the 
people around them politely in the same manner without considering their background (Moyses, 2013).

Further, the expression "I think Bono will win the race!" in Chapter 9 page 120 of the package book for grade VIII represents the Islamic character value of confidence. Confidence should be internalized in the students' mind by reading more of expressions and statements of confidence in the package book.

Meanwhile, the expression in Chapter 3 page 37 of the package book "Think Globally Act Locally ("Listen, everybody, never forget to wash your fruits and vegetables before you eat them.") can also show the character of a healthy lifestyle as one of the character values in Islam. This is in line with Suyanto (2012) that the students should obtain character education in their learning process, and this can be internalized in the English teaching and learning process. Sultoni (2016) added to this case that the integration of character education to the school subjects help cultivate and insert the intended values to be implemented in daily life as a habit.

Next, curiosity as a character value in Islam can also be observed in the package book for Grade VII Chapter 4 (Wachidah et al., 2017a). The expression "Do you know the building on the right, across the bank and the post office?" shows curiosity that leads the students to ask whenever they get stuck or do not understand. Being curious should always be internalized into the students' mind to be a habit so that they will always remember.

The last, motivation (internal) can also be found in the English package book. Expression in Chapter 2 (Wachidah et al., 2017b) of the package book 'When English Rings a Bell' for Grade VIII ("If you do it together, I am sure you can understand it easily.") might motivate students to do the same and make collaboration after they are learning the expression. Furthermore, character values of friendly life environment can also be traced in the package book 'Think Globally Act Locally' in Chapter 3: "Pick up the trash and put it in the bin" (Wachidah et al., 2015). After reading the statement, the students might strongly follow the act of keeping the environment clean. To integrate the character of being environmentally friendly to the teaching and the package books will help to raise the students' awareness and encourage their participation in creating a better living (Setyowati, 2013).

Furthermore, character values in the English package books above can be traced not only from the statements or expressions. Illustrations may also express character values; for example illustration of scouts lining up, orderly

Journal on English as a Foreign Language, 9(2), 181-198

Copyright (C) 2019 by JEFL, p-ISSN 2088-1657; e-ISSN 2502-6615 
may also show the implicit meaning of character values that can be taught to the students. Illustrations of students wearing a neat uniform, female students wearing hijab may also represent character values referred to Islamic religion (Usadiati, Fauzan, \& Norahmi, 2018).

To support the above elaborations, the result of teachers' interview conducted during the finding dissemination also showed the teachers' willingness to integrate character values in their preparation of developing supplementary materials in their teaching and learning process. They agreed that the abstract values should be displayed concretely through action, and one of the actions that can be done is to display the meaning of the values in the learning materials. This in line with the statement of Musrifah (2016) that character education has to be included in the teaching materials. By having supplementary materials referring to Islamic character values, students may become more interested since their need in practicing Islamic character values is exemplified and accommodated to become their daily habit both at school and at home.

These results all mean that the appeal of the government in the Naskah Rencana Aksi Nasional Pendidikan Karakter 2010 to include character education in the activities of teaching and learning process has been fulfilled in Curriculum 2013 and its elaboration. The expressions of religious values as the main pillars in education cannot be separated from character building in developing human resources through education. Jamaluddin (2013) added that the purpose to develop human resources by character education is to prepare the students to live in the present world and the future. In line with Musrifah (2016), that character education is an effort to teach good characters, morals, and ethics in daily life, habituation of good Islamic character values can thus be implanted to students through the teaching and learning process. That is why the education equipped with character-building inside will prepare and provide the students to survive throughout their lives.

\section{CONCLUSION}

Results of the inventory show an explicit relevance of the English expressions in the English Package Books for Grades VII, VIII, and IX of Islamic High School students with the character values of Islam stated in the Quran and Hadits. There are 133, 86, and 163 statements expressing honesty, discipline, responsibility, care (tolerance), politeness, confidence, curiosity, motivation (internal), healthy lifestyle, and the friendly live environment in the English Package Books for Grades VII, VIII, and IX respectively. These results will give 
new insights into what and how good values can be inserted as based on local content approach. The inventory list of the values should be shared with the English teachers in Palangka Raya. It is suggested that the teachers use the list as the guidance to develop teacher-made supplementary materials by inserting the values in reading texts, for example, on the topics of Islamic religious practices such as on the way to do ablution, requirements for Salat (prayer), stories of Islamic heroes/heroines, Islamic historical sites, and Islamic celebrations to display both character education and religious education to the students. Further research is still needed to facilitate the explicitness of the Islamic character values in the English materials to be developed. A model or a prototype of the teacher-made supplementary materials should be created by using $\mathrm{R} \& \mathrm{D}$ to guide and help the teachers in creating their materials and how the materials should be developed. As a long term expectation, the teachermade materials can be collected for publication and can be alternative materials of character education at greater scale.

\section{REFERENCES}

Berkowitz, M., \& Bier, M. (2007). What works in character education. Journal of Research in Character Education, 5(1), 29-48.

Bogdan, R.C., \& Biklen, S.K. (1982). Qualitative research for education: An introduction to theory and methods. Boston: Allyn and Bacon, Inc.

Budiwibowo, S. (2016). Membangun pendidikan karakter generasi muda melalui budaya kearifan lokal di era global. Premiere Educandu: Jurnal Pendidikan Dasar dan Pembelajaran, 3(01), 39-49. https://doi.org/10.25273/pe.v3i01.57

Gill, H. (2017, August 25). Is education keeping up with industry 4.0? Retrieved April 21, 2019, from Leaderonomics.com website: https://eaderonomics.com/personal/education-industry-4-0

Gunawan, H. (2012). Pendidikan karakter: Konsep dan Implementasi. Bandung: Alfabeta.

Hadi, R. (2015). The integration of character values in the teaching of economics: a case of selected high schools in Banjarmasin. International Education Studies, 8(7), 11-20. https://doi.org/10.5539/ies.v8n7p11

Indonesian Ministry of National Education. (2010). Naskah rencana aksi nasional pendidikan karakter. Indonesian Ministry of National Education.

Jamaluddin, D. (2013). Character education in Islamic perspective. International Journal of Scientific \& Technology Research Volume, 2(2), 187-189. 
Marini, A. (2017). Character building through teaching-learning process: Lesson in Indonesia. PONTE International Scientific Research Journal, 73(5), 177182. https://doi.org/10.21506/.ponte.2017.5.43

Moniung, V. Y., \& Prayogo, W. (2018, April 21). Implementation of pp 87/2017 on character education in elementary schools. Proceedings of International Conference on Child-Friendly Education, (pp. 286-290). Universitas Muhammadiyah Surakarta.

Moyses, K. (2013, October 17). Building character in children and youth - A bouncing and stretching article, part 2. Retrieved April 21, 2019, from MSU Extension website: https://www.canr.msu.edu/news building_character_in_children_and_y outh_a_bouncing_and_stretching_article-

Musrifah, M. (2016). Pendidikan karakter dalam perspektif Islam. Edukasia Islamika: Jurnal Pendidikan Islam, 1(1), 119-133.

Setyowati, L. (2013). Integrating character building into teaching to enhance the students environmental awareness. Journal on English as a Foreign Language, 3(1), 1-10. https://doi.org/10.23971 ßefl.v3i1.57

Sukardi, I. (2016). Character education based on religious values: an Islamic perspective. $\mathrm{Ta}^{\prime} \mathrm{dib}, 21(1), 41-58$.

Sultoni, A. (2016). Pendidikan karakter dan kemajuan negara. JOIES: Journal of Islamic Education Studies, 1(1), 167-188.

Sutarman, S., Edi Hermawan, H., \& Ahmad, A. (2017). Character education to build personal learners tough. IOSR Journal of Research $\mathcal{E}$ Method in Education (IOSRJRME), 07(1), 59-63. https://doi.org/10.9790/73880701055963

Sutjipto, S. (2011). Rintisan pengembangan pendidikan karakter di satuan pendidikan. Jurnal Pendidikan dan Kebudayaan, 17(5), 501-524.

Suyanto, S. (2012). Pendidikan karakter untuk anak usia dini. Jurnal Pendidikan Anak, 1(1), 1-10. https://doi.org/10.21831/ppa.v1i1.2898

Suyitno, I. (2012). Pengembangan pendidikan karakter dan budaya bangsa berwawasan kearifan lokal. Jurnal Pendidikan Karakter, 2(1), 1-13. https://doi.org/10.21831/jpk.v0i1.1307

The Indonesian Minister for Research, Technology, and Higher Education. (2018, January 22). Policies for Curriculum and Competencies in the 4th Industrial Revolution (4-IR). Presented at the Education World Forum, London. Retrieved from https://www.theewf.org/uploads/pdf/D1-16.00HE-Dr-Mohamad-Nasir.pdf 
The Indonesian Ministry of Education and Culture. (2013). Kurikulum 2013: Kompetensi Dasar Sekolah Menengah Pertama (SMP) / Madrasah Tsanawiyah (MTs). the Indonesian Ministry of Education and Culture.

Usadiati, W., Fauzan, A., \& Norahmi, M. (2018). Inventarisasi pendidikan karakter dalam buku ajar bahasa Inggris 'When English Rings a Bell' untuk siswa Madrasah Tsanawiyah dan madrasah aliyah. Palangka Raya: University of Palangka Raya (Unpublished Research Results).

Wachidah, S., Diyantari, \& Khatimah, Y.R. (2015). Bahasa Inggris, Think Globally act Locally: SMP/MTs kelas IX. Jakarta: Kementerian Pendidikan dan Kebudayaan.

Wachidah, S., Gunawan, A., Diyantari, \& Khatimah, Y.R. (2017a). Bahasa Inggris, When English Rings a Bell: SMP/MTs kelas VII. Edisi Revisi. Jakarta: Kementerian Pendidikan dan Kebudayaan.

Wachidah, S., Gunawan, A., Diyantari, \& Khatimah, Y.R. (2017b). Bahasa Inggris, When English Rings a ell: SMP/MTs kelas VIII. Edisi Revisi. Jakarta: Kementerian Pendidikan dan Kebudayaan.

\section{Authors' Brief CV}

Wahyuningsih Usadiati is a lecturer of Undergraduate and Graduate Program, University of Palangka Raya, Indonesia. Her interests include ELT, ESP, and English Material Development.

Maida Norahmi is a lecturer on English Education at the University of Palangka Raya. Her undergraduate and graduate degrees were pursued at the University of Palangka Raya (2011) and the State University of Malang (2014). Her interests are on Teacher Professional Development, English Material Development, and English Grammar Teaching. 